\title{
ANALISIS SPASIAL INDEKS KEKERINGAN DAERAH PANTAI UTARA (PANTURA) JAWA BARAT
}

\author{
Oleh : \\ Ch. Nasution dan Djazim Syaifullah \\ Peneliti UPTHB - BPPT
}

\begin{abstract}
Spatial analysis for water deficit in Pantura was done for 16 rainfall stations average 13 year observations. Water balance computation was calculated with Thornthwaite-Matter method. Spatial analisys was done by Geographys Information System (GIS) with Arclnfo 3.5 and displayed by ArcView 3.3. Water balance analysis shown that water deficit was on June for most of all stations and reached maximum deficit on August. Water deficit was concentred around of Batujaya (bekasi District), Peundeuy (Karawang district), and around of Leuweungsemut (Indramayu district). These result of the analysis recommended to plan the optimum water management for maximize purpose of Jatiluhur Lake
\end{abstract}

Kata kunci : Analisis spasial, Thornthwaite-Matter neraca air, indeks kekeringan

\section{PENDAHULUAN}

Air sebagai sumberdaya alam sangat diperlukan oleh semua mahkluk hidup untuk mempertahankan dan meningkatkan kualitas hidupnya. Pada beberapa wilayah ketersediaan air dapat mencukupi dan pada saat tertentu dapat juga menjadi kritis karena jauh berkurang. Terjadinya pergeseran musim yang mengakibatkan kemarau panjang sehingga terjadi kekeringan yang berpengaruh terhadap sektor pertanian. Kekeringa terjadi bukan saja karena berkurangnya curah hujan tetapi juga disebabkan oleh daya resap / tampung tanah yang sudah berkurang akibat rusaknya daerah resapan yang disebabkan penggunaan lahan yang tidak sesuai dengan peruntukannya.

Berdasarkan proyeksi kesetimbangan air untuk tiap kabupaten di Pulau Jawa untuk tahun 2020, menunjukkan bahwa sebagian besar daerah kondisi ketersediaan air sudah sangat mengkhawatirkan (Tabel 1). Potensi sumberdaya air suatu wilayah masih aman apabila total kebutuhan airnya kurang dari aliran rendah $10 \%$. Stasus waspada diberikan apabila total kebutuhan air wilayah berada diantara $10 \%$ hingga $45 \%$, sedangkan status kritis apabila melampaui batas aliran rendah 45\% (Nugroho, 2002).

Untuk lebih mengoptimalkan dalam pengelolaan sumberdaya air salah satunya perlu dilakukan analisis neraca air. Secara umum neraca air (water balance) menyatakan hubungan antara aliran air yang masuk (input) dengan aliran air yang keluar (output) pada suatu daerah pada waktu tertentu. Neraca air tersebut menurut fungsi meteorologis sangat diperlukan untuk mengevaluasi ketersediaan air hujan pada suatu wilayah tertentu, khususnya untuk mengetahui kapan dan seberapa besar surplus dan defisit air yang terjadi di wilayah yang ditinjau.

Tabel 1 Proyeksi kondisi Sumberdaya air tiap kabupaten di Pulau Jawa tahun 2020.

\begin{tabular}{|c|c|}
\hline Kondisi SD Air & Kabupaten \\
\hline Krisis & $\begin{array}{l}\text { Jakarta, Cirebon, Inramayu, } \\
\text { Purwakarta, Karawang, } \\
\text { Bekasi, Tangerang, Demak, } \\
\text { Bantul, Sidoarjo, Lamongan }\end{array}$ \\
\hline Waspada & $\begin{array}{l}\text { Bogor, Cianjur, Bandung, } \\
\text { Tasikmalaya, Ciamis, } \\
\text { Kuningan, Majalengka, } \\
\text { Sumedang, Kudus, Pati, } \\
\text { Rembang, Blora, Sragen, } \\
\text { Sukoharjo, Klaten,Yogyakarta, } \\
\text { Sidoharjo, Jombang, } \\
\text { Lamongan, Ngawi, Madiun, } \\
\text { Nganjuk, Kediri, Trenggalek, } \\
\text { Banyuwangi, Situbondo, } \\
\text { Sampang, Pamekasan }\end{array}$ \\
\hline Aman & Kabupaten Lainnya \\
\hline
\end{tabular}

Melalui perhitungan neraca air tersebut dapat dilakukan evaluasi secara tidak langsung terhadap komponen neraca air yang tidak diketahui besarnya berdasarkan komponen-komponen yang diketahui, misalnya besarnya defisit air pada bulan tertentu di wilayah tersebut. Chang (1968), menyatakan bahwa teknik neraca air telah banyak digunakan dalam pemecahan berbagai masalah seperti perencanaan sumberdaya air, klasifikasi iklim, peramalan banjir dan kebakaran hutan.

Tulisan ini melakukan analisis spasial indeks kekeringan daerah Pantura untuk 
mengetahui wilayah-wilayah mana saja yang terjadi intensitas kekeringan. Metode ini semakin berkembang dan populer digunakan oleh praktisi manajemen air karena sederhana dan praktis aplikasinya. Sebelumnya telah dilakukan pembuatan program perhitungan sederhana dari neraca air dengan metode Thornthwaite-Matter yang dapat digunakan untuk analisis defisit air. Manfaat dari program ini adalah dapat digunakan untuk mengetahui defisit air maupun surplusnya dari nilai indeks kekeringan sehingga dapat digunakan sebagai pertimbangan dalam manajemen air di wilayah tertentu.

\section{DATA DAN METODE}

\subsection{Daerah Penelitian}

Daerah penelitian adalah wilayah Pantai Utara (Pantura) Jawa Barat, secara administratif meliputi 5 (lima) Kabupaten, yaitu Kabupaten Bekasi, Karawang, Purwakarta, Subang dan Kabupaten Indramayu, seperti terlihat pada Gambar 1.

Daerah Pantura mempunyai curah hujan tahunan sekitar $1500 \mathrm{~mm}$ (dihitung dari 16 stasiun dengan data dari tahun 1990 sampai 2003). Puncak musim kering terjadi pada bulan Agustus sedangkan puncak musim basah terjadi pada bulan Januari.

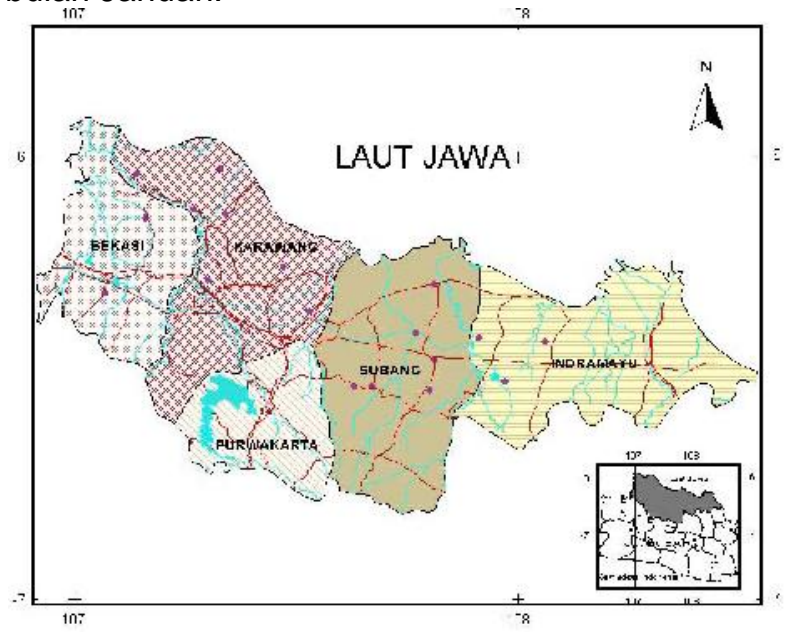

Gambar 1. Peta administratif wilayah penelitian

\subsection{Data}

Data yang dipakai adalah data curah hujan bulanan daerah Pantura Jawa Barat sebanyak 16 buah stasiun pengamatan hujan seperti terlihat pada Tabel 2. Disamping itu juga data suhu bulanan yang diambil dari beberapa stasiun yang mempunyai data pengamatan. Stasiun yang tidak mempunyai data pengamatan suhu diperoleh dengan melakukan pendugaan dari stasiun terdekat.
Tabel 2. Daftar Stasiun Curah Hujan beserta koordinat yang digunakan (sumber : UPT Hujan Buatan Jakarta)

\begin{tabular}{|c|c|c|c|c|}
\hline No & Nama & Bujur & Lint & Elevasi \\
\hline 1 & Srengseng & 107.16 & -6.14 & 8 \\
\hline 2 & Setu & 107.07 & -6.31 & 15 \\
\hline 3 & Karawang & 107.30 & -6.28 & 14 \\
\hline 4 & Rengasdengklok & 107.27 & -6.12 & 7 \\
\hline 5 & Batujaya & 107.14 & -6.04 & 6 \\
\hline 6 & Pedes & 107.33 & -6.03 & 2 \\
\hline 7 & Pondokbalas & 107.34 & -6.13 & 4 \\
\hline 8 & Peundeuy & 107.47 & -6.25 & 7 \\
\hline 9 & Pagaden & 107.81 & -6.46 & 90 \\
\hline 10 & Cipeundeuy & 107.63 & -6.50 & 100 \\
\hline 11 & Pamanukan & 107.78 & -6.27 & 14 \\
\hline 12 & Tanjung & 107.50 & -6.33 & 10 \\
\hline 13 & Leuweungsemut & 108.03 & -6.42 & 40 \\
\hline 14 & Gantar & 107.95 & -6.50 & 80 \\
\hline 15 & Kalijati (Subang) & 107.63 & -6.52 & 110 \\
\hline 16 & Jatiwangi & 108.27 & -6.73 & 50 \\
\hline
\end{tabular}

\subsection{Metode}

Metode perhitungan neraca air dilakukan dengan membuat Tabel Neraca Air dari parameter hidrologi dengan melakukan beberapa perhitungan empiris. Langkahlangkah yang dilakukan melalui beberapa tahapan perhitungan sebagai berikut (Nugroho, 1998) :

a. Data rerata curah hujan bulanan $(P, m m)$ Data curah hujan yang dipakai adalah data historis bulanan untuk 16 stasiun curah hujan yang ada di wilayah Pantura.

b. Suhu udara bulanan $\left(t,{ }^{\circ} \mathrm{C}\right)$

Apabila tidak terdapat data pengamatan suhu udara dapat dilakukan dengan melakukan pendugaan dari stasiun terdekat dengan memperhitungkan faktor ketinggian tempat dengan persamaan Mock (1973) :

$$
\Delta t=0.006 \cdot\left(z_{1}-z_{2}\right)
$$

dengan :

$\Delta \mathrm{t}$ : perbedaan suhu antara stasiun pengukuran dengan yang dianalisis. $\left({ }^{\circ} \mathrm{C}\right)$

$\mathrm{Z}_{1}$ : elevasi stasiun pengukuran suhu $(\mathrm{m})$ $\mathrm{Z}_{2}$ : elevasi stasiun yang dianalisis $(\mathrm{m})$

Karena keterbatasan data suhu, maka dipakai sata suhu bulanan historis di dua stasiun yaitu Stasiun Jatiwangi dan Stasiun Kalijati (Subang). Gambar 2 adalah profil suhu bulanan historis kedua stasiun tersebut. 


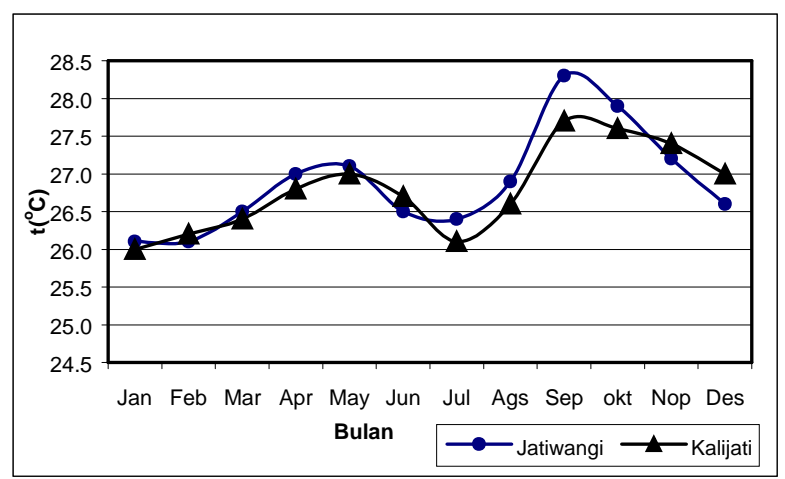

Gambar 2. Profil suhu bulanan historis stasiun Jatiwangi dan Kalijati (Sumber UPT Hujan Buatan Jakarta)

\section{c. Evapotranspirasi Potensial (PE)}

Evapotranspirasi potensial (PE) adalah kemampuan total udara untuk melakukan penguapan saat persediaan kelembaban untuk vegetasi tidak terbatas (llaco, 1981). Evapotranspitrasi potensial untuk tiap bulannya dihitung dengan metode Thornthwaite-Matter dengan persamaan :

$$
\begin{gathered}
P E_{x}=16 \cdot(10 \cdot t / I)^{a} \\
P E=P E_{x} \cdot f
\end{gathered}
$$

dimana :

$P E_{\mathrm{x}}$ : Evapotranspirasi potensial yang belum disesuaikan dengan faktor koreksi (f)

$\mathrm{PE} \quad$ : Evapotranspirasi potensial $(\mathrm{mm})$

$\mathrm{t}$ : suhu rerata bulanan $\left({ }^{\circ} \mathrm{C}\right)$

$f$ : faktor koreksi berdasarkan letak lintang dan waktu

I : jumlah nilai i dalam setahun dengan $\mathrm{i}=(\mathrm{t} / 5)^{1.514}$.

$a=\left(0.675 \cdot 10^{-6} \cdot I^{3}\right)-\left(0.77 \cdot 10^{-4} \cdot I^{2}\right)+$ $0.01792 . I+0.49239$

Faktor koreksi (f) dapat diperoleh dari Tabel Koreksi (Thornthwaite and Mather, 1957).

d. Water Holding Capacity (WHC)

WHC atau kapasitas lengas tanah adalah tebal air $(\mathrm{mm})$ pada setiap kedalaman lapisan tanah. Nilai WHC tergantung pada jenis tanah (tekstur) dan kedalaman perakaran tanaman. Dengan bantuan tabel pendugaan yang dikombinasikan kedalaman perakaran pada berbagai tekstur tanah, nilai WHC dapat diperoleh.

e. Selisih antara $P$ dengan PE tiap bulan

f. Akumulasi hilangnya air potensial (Accumulated Potential Water Loss APWL)

- Pada bulan-bulan kering atau yang nilai presipitasinya lebih kecil dari nilai evapotranspirasi potensial $(P<P E)$, dilakukan dengan cara menjumlahkan nilai selisih (P-PE) setiap bulan dengan nilai ( $P$ $P E)$ bulan sebelumnya.

- Pada bulan-bulan basah (P>PE), maka nilai APWL sama dengan nol. g. Kelengasan tanah (St)

- Pada bulan-bulan basah (P>PE), nilai St untuk tiap bulannya sama dengan WHC

- Pada bulan-bulan kering $(\mathrm{P}<\mathrm{PE})$ nilai St untuk tiap bulannya dihitung dengan persamaan :

$$
S_{t}=S_{t 0} \cdot e^{-\left(A P W L / S_{t o}\right)}
$$

dimana :

St : Storagekelengasan tanah (mm)

Sto : Kelengasan tanah pada kapasitas lapang $(\mathrm{mm})$

APWL : akumulasi hilangnya air potensial $(\mathrm{mm})$

h. Perubahan kelengasan tanah tiap bulan $(\Delta S t)$

i. Evapotranspirasi Aktual (AE)

- Untuk bulan-bulan basah (P>PE), maka nilai $A E=P E$

- Untuk bulan-bulan kering $(P<P E)$, maka nilai $\mathrm{AE}=\mathrm{P}-\Delta \mathrm{St}$

j. Moisture Deficiency (D)

Defisit atau kekurangan lengas tanah yang terjadi pada bulan-bulan $(\mathrm{P}<\mathrm{PE})$ diperoleh dari selisih antara PE dengan $\mathrm{AE}$

k. Moisture Surplus (S)

Surplus atau kelebihan lengas tanah yang terjadi pada bulan-bulan P>PE diperoleh dengan : $\mathrm{S}=(\mathrm{P}-\mathrm{PE})-\Delta \mathrm{St}$.

I. Indeks Kekeringan (la)

Indeks kekeringan dihitung dengan nilai prosentase perbandingan antara nilai defisit air dengan Potensial Evaporasi

$$
\mathrm{la}=(\mathrm{D} / \mathrm{PE}) * 100 \%
$$

\subsection{Analisis Spasial}

Sebelum dilakukan analisis spasial maka untuk setiap stasiunnya dilakukan analisis kesetimbangan air, sampai diperoleh nilai Indeks Kekeringan (la). Data curah hujan bulanan dengan 16 buah stasiun diperoleh dari UPT hujan Buatan BPPT Jakarta. Masing-masing stasiun dibuat curah hujan bulanan historis, data suhu bulanan dibangkitkan dengan Persamaan 1. Setelah itu dibuat perhitungan kesetimbangan air untuk mengetahui indeks kekeringan setiap bulannya.

Analisis spasial dilakukan dengan Sistem Informasi Geografi (SIG), dengan menggunakan Arclnfo 3.5, ArcView 3.3 Copyright ESRI Inc. Peta kontur dibuat dengan program Surfer Ver. 8.0 Copyright Golden Software Inc. Proses gridding dilakukan dengan metode krigging. Setelah semua stasiun dilakukan analisis neraca air, 
maka dilakukan analisis spasial dengan membuat peta tematik masing-masing parameter (curah hujan, indeks kekeringan) setiap bulannya. Pembuatan peta dasar dilakukan dengan ArcView dalam bentuk peta administrasi Pantura. Peta tematik lain yang perlu disiapkan adalah peta Sungai, Jalan, Danau/waduk dan Stasiun penakar. Hasil kontur dari program Surfer dieksport ke dalam bentuk shapefile dan dibangun topologinya oleh Arclnfo untuk bisa dioverlay-kan dengan petapeta tematik lainnya dalam ArcView.

\section{HASIL}

\subsection{Kondisi Curah Hujan wilayah Pantura}

Curah hujan historis maksimum untuk wilayah Pantura terjadi pada Bulan Januari dan curah hujan minimumnya terjadi pada Bulan Agustus. Dari kriteria BMG menetapkan bahwa bulan basah adalah bulan yang curah hujannya melebihi $150 \mathrm{~mm} / \mathrm{bulan}$. Dari kriteria tersebut dan melihat dari Gambar 3, maka pola curah hujan bulanan daerah Pantura secara klimatologis mempunyai bulan basah dari bulan Nopember sampai April.

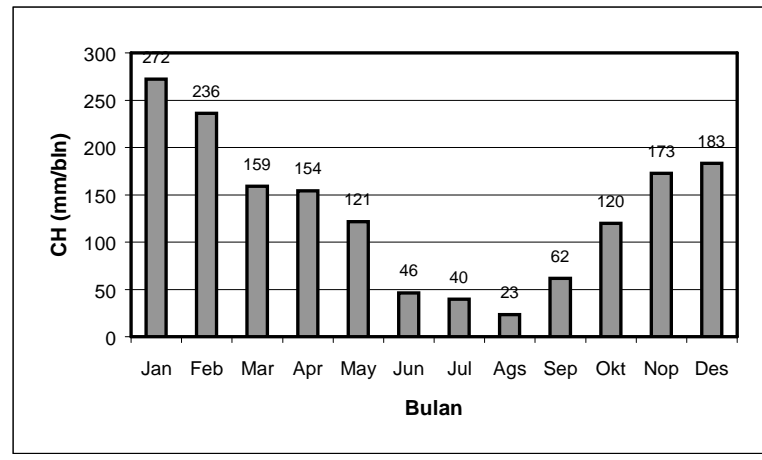

Gambar 3. Profil curah hujan bulanan Wilayah Pantura dari 16 buah stasiun.

Analisis curah hujan menggunakan data curah hujan wilayah yang dihitung berdasarkan rerata aritmatik tidak dapat menggambarkan sebaran curah hujan, sementara informasi sebaran curah hujan (informasi spasial) penting dalam kaitannya dengan menentukan daerahdaerah mana yang mempunyai curah hujan minimum yang berkorelasi dengan defisit air.

\subsection{Neraca Air wilayah Pantura}

Sebanyak 16 stasiun dilakukan analisis kesetimbangan air, sehingga diketahui apakah pada bulan tersebut terjadi surplus atau defisit air. Pada Tabel L1 sampai Tabel L4 Lampiran1 diberikan contoh analisis kesetimbangan air untuk 4 (empat) dari 16 (tujuh belas) buah stasiun yaitu : Stasiun Batujaya, Stasiun Pamanukan; Stasiun Karawang dan Stasiun Leuweung Semut.
Neraca air historis untuk Stasiun Batujaya mulai mengalami defisit pada bulan April sampai Nopember, indeks kekeringan maksimum terjadi pada bulan Agustus sebesar $70 \%$. Stasiun Pamanukan mulai mengalami defisit pada bulan Juni sampai Oktober, indeks kekeringan maksimum terjadi pada bulan Agustus sebesar $48 \%$. Stasiun Karawang mulai mengalami defisit pada bulan Juni sampai Nopember, indeks kekeringan maksimum terjadi pada bulan Agustus sebesar $71 \%$. Stasiun Leuweungsemut mulai mengalami defisit pada bulan Maret sampai Oktober, indeks kekeringan maksimum terjadi pada bulan Agustus sebesar 63\%. Dari hasil analisis keempat stasiun tersebut ternyata nilai indeks kekeringan maksimum tercapai pada bulan Agustus.

Secara wilayah dari nilai indeks kekeringan jika dilihat dari Gambar 4 sejak Bulan Juni Pantura mulai mengalami defisit air dan mencapai puncaknya pada Bulan Agustus sebesar $61 \%$ berkorelasi dengan curah hujan minimum yang terjadi pada Bulan yang sama.

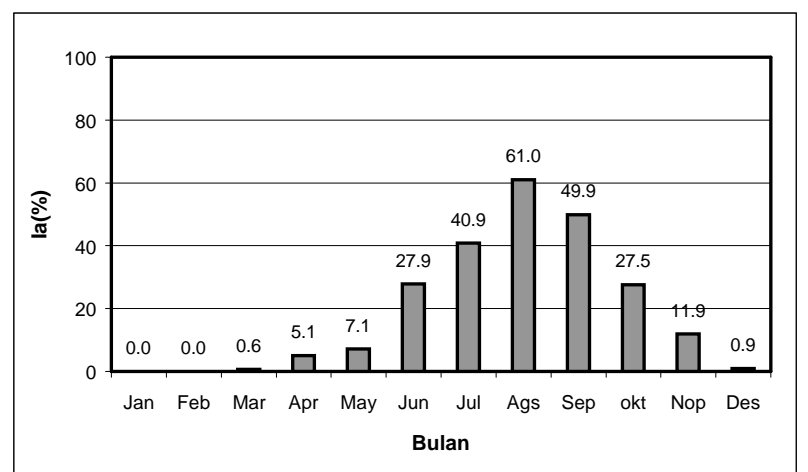

Gambar 4. Profil Indeks Kekeringan (la, \%) Daerah Pantura

Untuk melihat sebaran defisit air secara keseluruhan dapat dilihat dari hasil analisis spasialnya yang dilakukan terhadap bulanbulan tertentu (bulan kering). Dengan membandingkan analisis spasial curah hujan dengan analisis spasial indeks kekeringan maka dapat dipelajari daerah-daerah yang potensial rawan bencana kekeringan dan kebakaran lahan.

\subsection{Analisis Spasial Curah Hujan wilayah Pantura}

Analisis spasial dilakukan terhadap data historis curah hujan dari 16 buah stasiun penakar hujan. Dari Gambar 3 terlihat profil curah hujan wilayah Pantura mencapai minimum pada bulan-bulan Juni, Juli dan Agustus, sehingga untuk mengetahui sebaran 
curah hujannya dilakukan analisis pada bulanbulan tersebut.

Hasil analisis spasial terhadap curah hujan historis bulan Juni, Juli dan Agustus dapat dilihat pada Gambar 5, 6 dan 7 berikut :

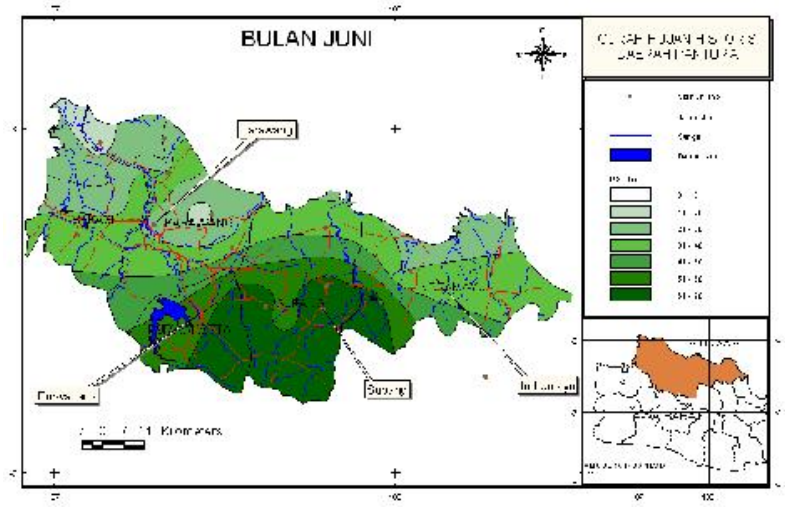

Gambar 5. Peta isohyet historis bulan Juni Wilayah Pantura

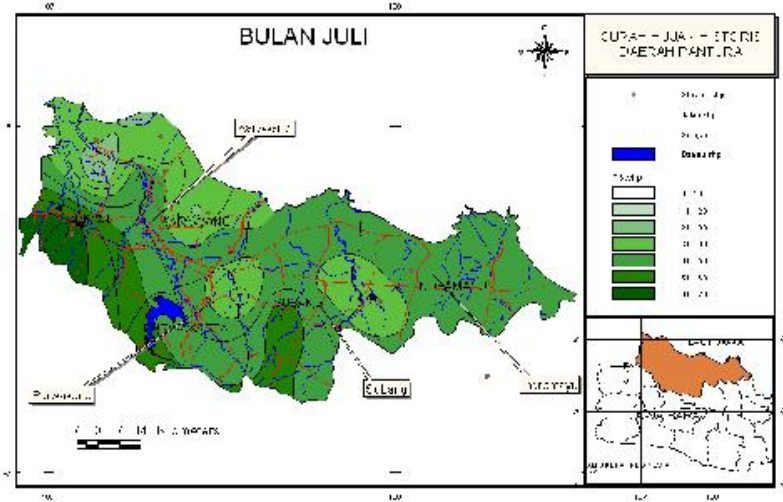

Gambar 6. Peta isohyet historis bulan Juli Wilayah Pantura

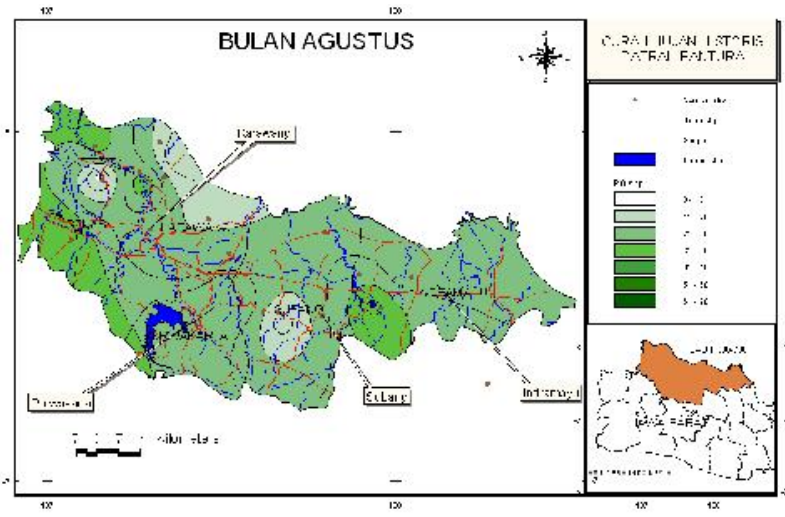

Gambar 7. Peta isohyet historis bulan Agustus Wilayah Pantura

Dari Gambar 5, 6 dan 7 terlihat bahwa sebaran curah hujan terkonsentrasi di bagian Selatan dan memasuki bulan Agustus wilayah Pantura sudah mengalami penurunan curah hujan.

\subsection{Analisis Spasial Indeks Kekeringan wilayah Pantura}

Indeks kekeringan (la) didefinisikan sebagai prosentase perbandingan antara nilai defisit air dengan Potensial Evaporasi seperti dalam persamaan di atas. Untuk melihat tingkat kekeringan maka indeks kekeringan dibagi dalam tiga skala yaitu skala sedikit (tidak ada), sedang dan besar. Skala sedikit (tidak ada) apabila nilai indeks kekeringan berada dalam batas $0-16.7$, skala sedang jika nilai indeks kekeringan berada di $16.7 \sim 33.3$, sedangkan skala besar jika nilainya antara 33.3 sampai dengan 100 .

Hasil analisis spasial terhadap indeks kekeringan air historis untuk masing-masing bulan selengkapnya ada di Lampiran 2 . Gambar 8 adalah contoh hasil analisis spasial indeks kekeringan untuk Bulan Agustus, sedangkan untuk Gambar 9 adalah contoh hasil analisis spasial indeks kekeringan untuk Bulan September.

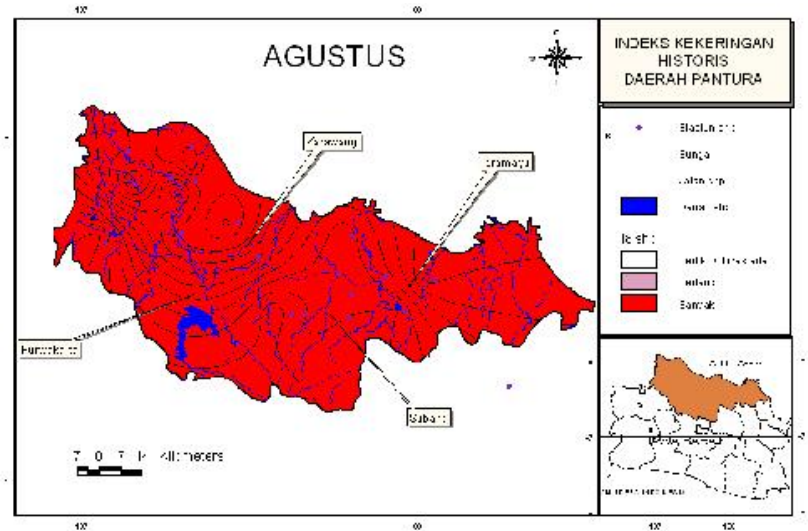

Gambar 8. Peta Indeks Kekeringan (la) historis wilayah Pantura bulan Agustus.

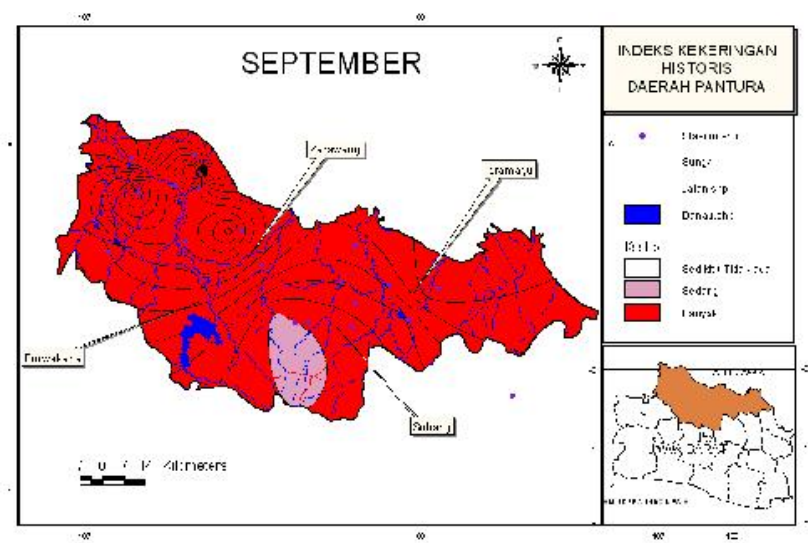

Gambar 9. Peta Indeks Kekeringan (la) historis wilayah Pantura bulan September.

Dari hasil analisis spasial terhadap indeks kekeringan air historis untuk setiap bulannya seperti terlihat pada Lampiran 2 menunjukkan bahwa daerah Pantura pada Bulan Januari, Februari, Maret dan Desember daerah Pantura tidak mengalami kekeringan. Mulai memasuki bulan April sudah nampak 
adanya daerah kekeringan dengan skala sedang di daerah pesisir utara bagian Barat dan areanya semakin meluas pada bulan Mei. Pada bulan Juni luasan yang dimulai dari pesisir utara bagian barat semakin lebar dengan intensitas kekeringan yang semakin bertambah, disamping itu juga wilayah pesisir bagian Timur pada bulan ini juga sudah mengalami kekeringan dengan skala besar yang pada bulan sebelumnya tidak nampak.

Pada bulan Agustus dan September semua wilayah Pantura mengalami kekeringan dengan indeks diatas 33.3, sedangkan pada Bulan Oktober bagian selatan Pantura sudah mulai menurun tingkat kekeringan, sementara bagian pesisir masih nampak mengalami kekeringan. Secara umum pergerakan daerah rawan kekeringan dari bulan basah ke bulan kering dimulai dari pesisir utara bagian Barat dan Timur, bergerak ke arah Selatan. Sedangkan memasuki bulan basah luasan daerah rawan kekeringan berkurang dari selatan ke pesisir utara bagian barat.

\section{KESIMPULAN}

Dari hasil analisis neraca air ternyata dapat diperlihatkan bahwa mulai bulan Juni hampir semua stasiun sudah mengalami kekeringan. Daerah sekitar Stasiun Pedes, Batujaya dan PondokBalas (Kabupaten Karawang) mempunyai tingkat indeks kekeringan paling besar dibandingkan daerah lain dan mencapai puncaknya pada Bulan Agustus. Memasuki bulan kering wilayah pesisir bagian Barat dan Timur mengalami indeks kekeringan terlebih dahulu kemudian menyebar ke arah Selatan.

\section{Ucapan Terimakasih}

Ucapan terimakasih disampaikan kepada Bagian Data UPT Hujan Buatan, dan para peneliti Tim
Indeks kekeringan UPTHB atas segala masukan dan kontribusi data terhadap tulisan ini.

\section{Daftar Pustaka}

1. Chang, JH, 1974, Climate and Agriculture, An Ecological Survey. Aldine Publishing Company, Chicaho

2. Mock, F. J. 1973. Land Capability Apprassial Indonesia, Water Available Apprassial. FAO/UNDP. Working Paper No. 1. Bogor. Indonesia

3. Montheith, J. L. 1977. Climate. Academic Press. Inc. New York

4. Monteith, J. L and Unsworth, M. H. 1990. Principles of Environmental Physics, Edward Arnold, London

5. Nugroho, S.P dan Tikno, S 2002. Evaluasi Pengingkatan Hasil Curah Hujan dan Ketersediaan Air akibat Kegiatan Teknologi Modifikasi Cuaca di DAS Citarum. Jurnal Sains \& Teknologi Modifikasi Cuaca Vol.3 No.12002.

6. Syaifullah, D. 2004. Pembuatan Software Model Neraca Air Metode ThornthWaiteMather, Laporan Teknis Intern.

7. Syaifullah, D. 2004. Analisis Spasial defisit Air daerah Kalimantan Selatan dan Peluang Penerapan Teknologi Cuaca, Jurnal Meteorologi dan Geofisika Vol. 5 No. 3 Jakarta.

8. Thornthwaite, C. W. and J. R. Mather, 1957. Instruction and Tables for Computing Potential Evapotranspiration and the Water Balance. Publ. In Clim. Vol. X No. 3. Centerton. New Jesrey

9. Wiesner, C. J. 1970. Hydrometeorology. Chapmann and Hall. London 
Lampiran 1

Tabel L1. Tabel neraca air historis Stasiun Batujaya (koordinat : 107.15BT, 6.05LS, elevasi $6 \mathrm{~m}$ )

\begin{tabular}{|c|c|c|c|c|c|c|c|c|c|c|c|c|}
\hline Bulan & Jan & Feb & Mar & Apr & Mei & Jun & Jul & Ags & Sep & Okt & Nop & Des \\
\hline P & 353 & 233 & 116 & 45 & 90 & 18 & 30 & 33 & 84 & 52 & 45 & 188 \\
\hline T & 25.4 & 25.6 & 25.8 & 26.2 & 26.4 & 26.1 & 25.5 & 26 & 27.1 & 27 & 26.8 & 26.4 \\
\hline PE & 125 & 115 & 128 & 130 & 136 & 130 & 122 & 132 & 145 & 152 & 147 & 147 \\
\hline P-PE & 228 & 118 & -12 & -85 & -46 & -112 & -92 & -99 & -61 & -100 & -102 & 41 \\
\hline APWL & 0 & 0 & -12 & -97 & -143 & -255 & -347 & -445 & -506 & -606 & -708 & 0 \\
\hline ST & 150 & 150 & 139 & 79 & 58 & 27 & 15 & 8 & 5 & 3 & 1 & 150 \\
\hline dST & 0 & 0 & -11 & -60 & -21 & -31 & -13 & -7 & -3 & -2 & -1 & 149 \\
\hline AE & 125 & 115 & 127 & 105 & 111 & 49 & 43 & 40 & 87 & 54 & 46 & 147 \\
\hline D & 0 & 0 & 0 & 25 & 25 & 82 & 79 & 92 & 58 & 97 & 101 & 0 \\
\hline S & 228 & 118 & 0 & 0 & 0 & 0 & 0 & 0 & 0 & 0 & 0 & -108 \\
\hline Ia & 0 & 0 & 0 & 19 & 19 & 63 & 65 & 70 & 40 & 64 & 69 & 0 \\
\hline
\end{tabular}

Tabel L2. Tabel neraca air historis Stasiun Pamanukan (koordinat : 107.78BT, 6.27LS, elevasi $14 \mathrm{~m}$ )

\begin{tabular}{|c|c|c|c|c|c|c|c|c|c|c|c|c|}
\hline Bulan & Jan & Feb & Mar & Apr & Mei & Jun & Jul & Ags & Sep & Okt & Nop & Des \\
\hline P & 347 & 222 & 228 & 187 & 166 & 44 & 43 & 23 & 54 & 102 & 188 & 142 \\
\hline T & 25.4 & 25.6 & 25.8 & 26.2 & 26.4 & 25.1 & 25.5 & 26 & 27.1 & 27 & 26.8 & 26.4 \\
\hline PE & 125 & 116 & 128 & 131 & 137 & 131 & 123 & 133 & 146 & 153 & 148 & 148 \\
\hline P-PE & 222 & 106 & 100 & 56 & 29 & -87 & -80 & -110 & -92 & -51 & 40 & -6 \\
\hline APWL & 0 & 0 & 0 & 0 & 0 & -87 & -167 & -276 & -368 & -419 & 0 & -6 \\
\hline ST & 250 & 250 & 250 & 250 & 250 & 176 & 128 & 83 & 57 & 47 & 250 & 244 \\
\hline dST & 0 & 0 & 0 & 0 & 0 & -74 & -48 & -46 & -25 & -11 & 203 & -6 \\
\hline AE & 125 & 116 & 128 & 131 & 137 & 118 & 91 & 69 & 79 & 113 & 148 & 148 \\
\hline D & 0 & 0 & 0 & 0 & 0 & 14 & 31 & 64 & 66 & 40 & 0 & 0 \\
\hline S & 222 & 106 & 100 & 56 & 29 & 0 & 0 & 0 & 0 & 0 & -163 & 0 \\
\hline la & 0 & 0 & 0 & 0 & 0 & 10 & 26 & 48 & 45 & 26 & 0 & 0 \\
\hline
\end{tabular}

Tabel L3. Tabel neraca air historis Karawang (koordinat : 107.28BT, 6.30LS, elevasi 14m)

\begin{tabular}{|c|c|c|c|c|c|c|c|c|c|c|c|c|}
\hline Bulan & Jan & Feb & Mar & Apr & Mei & Jun & Jul & Ags & Sep & Okt & Nop & Des \\
\hline P & 280 & 265 & 152 & 129 & 93 & 39 & 46 & 20 & 55 & 95 & 130 & 175 \\
\hline T & 25.4 & 25.6 & 25.8 & 26.2 & 26.4 & 26.1 & 25.5 & 26 & 27.1 & 27 & 26.8 & 26.4 \\
\hline PE & 125 & 116 & 128 & 131 & 137 & 131 & 122 & 133 & 146 & 153 & 148 & 148 \\
\hline P-PE & 155 & 149 & 24 & -2 & -44 & -92 & -76 & -113 & -61 & -58 & -18 & 27 \\
\hline APWL & 0 & 0 & 0 & -2 & -46 & -138 & -214 & -327 & -418 & -475 & -494 & 0 \\
\hline ST & 150 & 150 & 150 & 148 & 111 & 60 & 36 & 17 & 9 & 6 & 6 & 150 \\
\hline dST & 0 & 0 & 0 & -2 & -38 & -51 & -24 & -19 & -8 & -3 & -1 & 144 \\
\hline AE & 125 & 116 & 128 & 131 & 131 & 90 & 70 & 39 & 63 & 98 & 131 & 148 \\
\hline D & 0 & 0 & 0 & 0 & 6 & 41 & 53 & 94 & 83 & 55 & 17 & 0 \\
\hline S & 155 & 149 & 24 & 0 & 0 & 0 & 0 & 0 & 0 & 0 & 0 & -117 \\
\hline la & 0 & 0 & 0 & 0 & 5 & 32 & 43 & 71 & 57 & 36 & 12 & 0 \\
\hline
\end{tabular}

Tabel L4. Tabel neraca air historis Stasiun Leuweung Semut (koordinat : 108.03BT,6.42LS, elevasi 40 m)

\begin{tabular}{|c|c|c|c|c|c|c|c|c|c|c|c|c|}
\hline Bulan & Jan & Feb & Mar & Apr & Mei & Jun & Jul & Ags & Sep & Okt & Nop & Des \\
\hline $\mathrm{P}$ & 186 & 201 & 97 & 90 & 100 & 40 & 44 & 22 & 65 & 99 & 182 & 150 \\
\hline $\mathrm{T}$ & 25.6 & 25.8 & 26 & 26.4 & 26.6 & 26.3 & 25.7 & 26.2 & 27.3 & 27.2 & 27 & 26.6 \\
\hline $\mathrm{PE}$ & 128 & 118 & 131 & 133 & 140 & 134 & 125 & 135 & 148 & 156 & 151 & 151 \\
\hline $\mathrm{P}-\mathrm{PE}$ & 58 & 83 & -34 & -43 & -40 & -94 & -81 & -113 & -83 & -57 & 31 & -1 \\
\hline $\mathrm{APWL}$ & 0 & 0 & -34 & -77 & -117 & -211 & -292 & -405 & -488 & -545 & 0 & -1 \\
\hline $\mathrm{ST}$ & 250 & 250 & 218 & 184 & 157 & 108 & 78 & 50 & 35 & 28 & 250 & 249 \\
\hline $\mathrm{dST}$ & 0 & 0 & -32 & -35 & -27 & -49 & -30 & -28 & -14 & -7 & 222 & -1 \\
\hline $\mathrm{AE}$ & 128 & 118 & 129 & 125 & 127 & 89 & 74 & 50 & 79 & 106 & 151 & 151 \\
\hline $\mathrm{D}$ & 0 & 0 & 2 & 9 & 13 & 45 & 51 & 85 & 69 & 50 & 0 & 0 \\
\hline $\mathrm{S}$ & 58 & 83 & 0 & 0 & 0 & 0 & 0 & 0 & 0 & 0 & -191 & 0 \\
\hline la & 0 & 0 & 2 & 6 & 9 & 33 & 41 & 63 & 47 & 32 & 0 & 0 \\
\hline
\end{tabular}




\section{Lampiran 2}

Peta indeks kekeringan historis wilayah Pantura selama 12 bulan
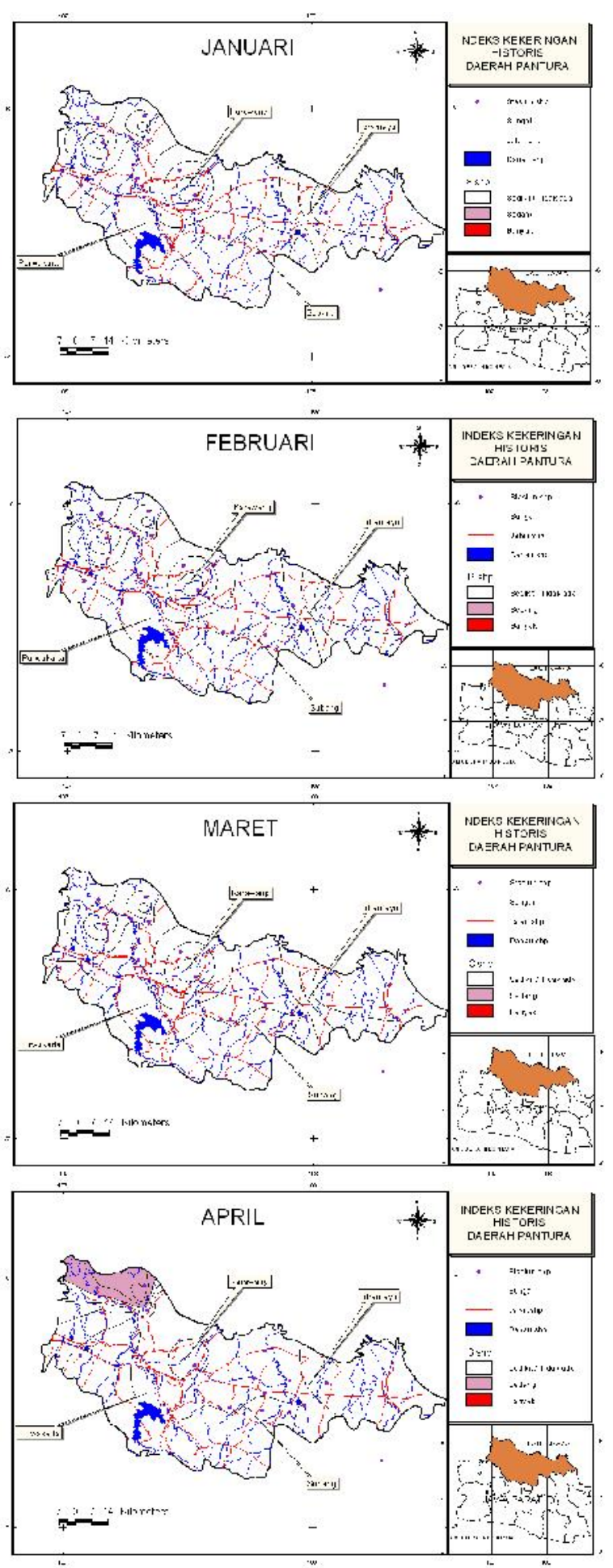
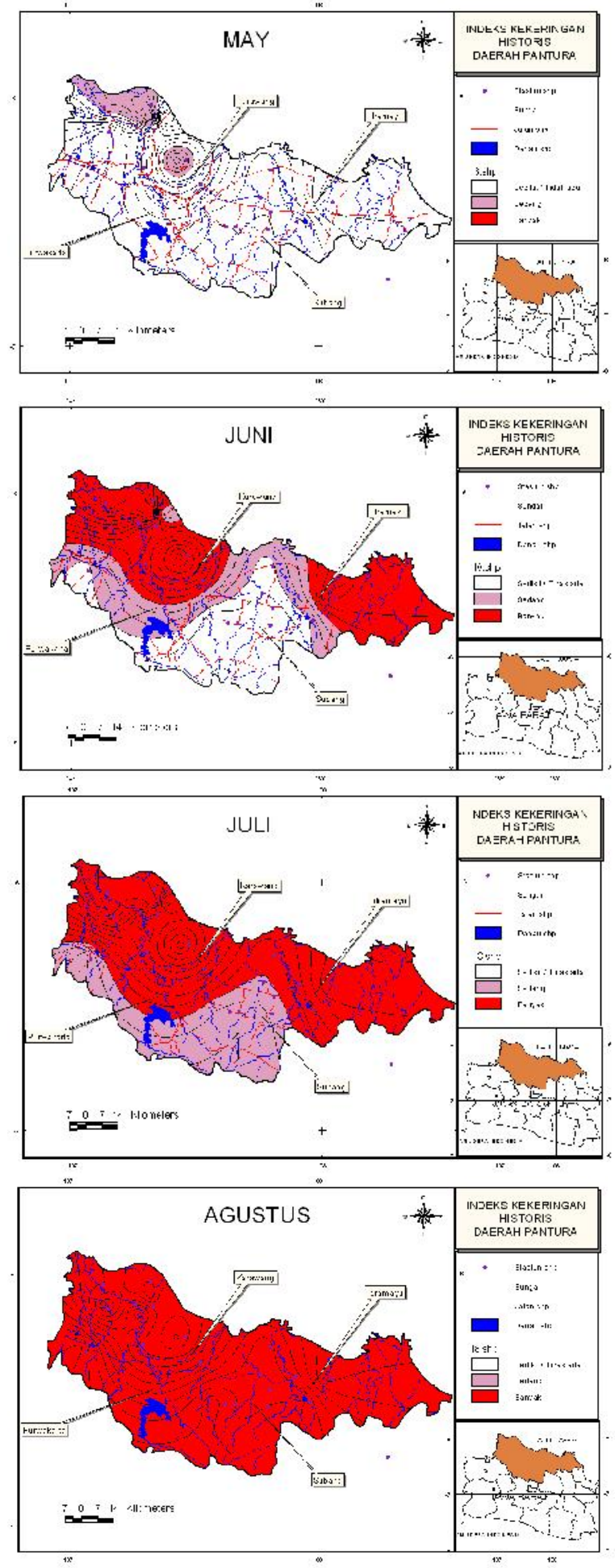


\section{Lampiran 2 (lanjutan..)}
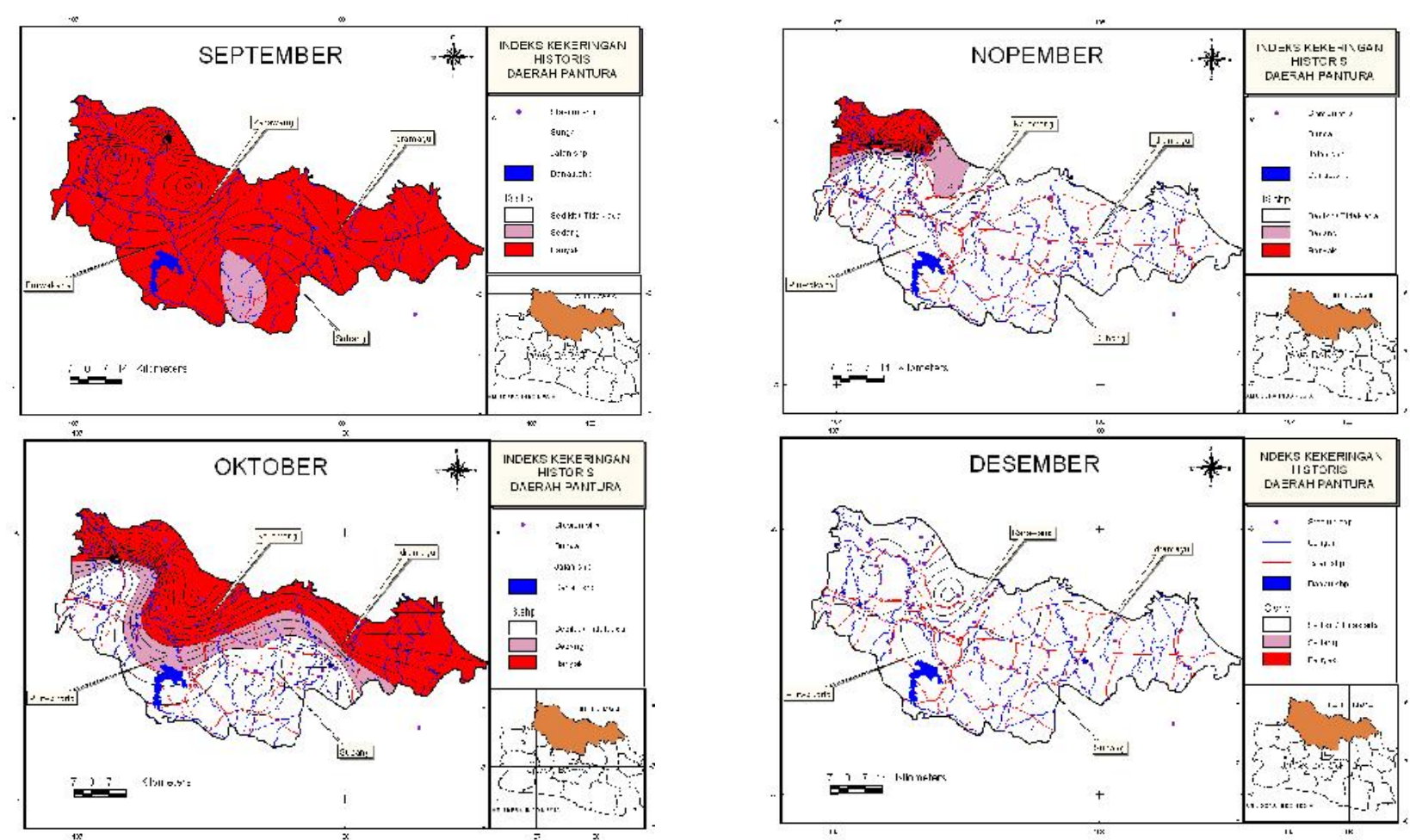